Article

\title{
Technological Response Options after the VW Diesel Scandal: Implications for Engine $\mathrm{CO}_{2}$ Emissions
}

\author{
Otto Andersen ${ }^{1, *(1)}$, Paul Upham ${ }^{2}$ (D) and Carlo Aall ${ }^{1}$ \\ 1 Stiftinga Vestlandsforsking (VESTFORSK), Fosshaugane Campus, Pb. 163, N-6851 Sogndal, Norway; \\ caa@vestforsk.no \\ 2 Institute for Environmental and Sustainability Communication (INFU), Leuphana University of Lüneburg, \\ Universitätsallee 1, 21335 Lüneburg, Germany; paul.upham@leuphana.de \\ * Correspondence: oan@vestforsk.no
}

Received: 23 April 2018; Accepted: 17 June 2018; Published: 4 July 2018

\begin{abstract}
In the VW diesel scandal, automakers were found to be cheating with emission data, by e.g., tampering with on-board detection systems. We have calculated changes in the energy use and emissions of carbon dioxide equivalents that would arise through several options open to automakers, to ensure that the emission of nitrogen oxides is kept within the standards. Several studies show how manufacturers have also significantly underreported vehicles' actual fuel consumption. We explain our derivation of new factors for energy consumption and greenhouse gas emissions from diesel- and gasoline-powered passenger cars, as well as their electric hybrid varieties. The results of the analysis show that energy consumption and emissions of carbon dioxide equivalents will increase in the range of $18-21 \%$ for passenger cars with diesel and hybrid diesel engines, while for cars with gasoline and hybrid gasoline, the addition is $9-10 \%$. The analysis highlights an environmental dilemma of current car technology, but also the path-dependent ways of thinking that have been prevalent within the automotive sector. From a sociotechnical sustainability transitions perspective, Dieselgate can be viewed as a case of "regime resistance", whereby incumbent actors seek to maintain the status quo.
\end{abstract}

Keywords: transport policies; unintended consequences; climate gas emissions; Dieselgate scandal; energy use; transport; $\mathrm{NO}_{\mathrm{x}}$ reduction technologies; regime resistance

\section{Introduction}

Writing in 2009, Hoen et al. observed that attempting to achieve a transition to low carbon mobility consistent with stringent climate targets by relying on technological substitution alone is implausible [1]. This is because the technological options required are not yet ready in forms that are publicly acceptable in terms of cost and function. Nearly a decade later, how much has changed? On the one hand, major auto-manufacturers have committed to including electric vehicles (EVs) in their production lines. On the other hand, not only does the production of vehicles based on internal combustion engines continue apace, but the practical problems associated with EV deployment are far from resolved: issues of adequate fiscal subsidy and business/leasing models; national and international networks of charging points; impacts on power grids from multiple co-located EVs; lithium sourcing and sustainability; development of production and maintenance supply chains; recycling; and consumer perceptions [2].

The recent large-scale cheating with diesel exhaust emissions is often referred to as "Dieselgate"a name inspired by Watergate, the major political scandal in the United States during the early 1970s. The scandal peaked when VW admitted to having installed illegal software in 11 million diesel cars. On-board detection (OBD) programs were programmed to detect when cars are subjected to testing in laboratories, and the software changed the operating parameters of the cars so that $\mathrm{NO}_{\mathrm{x}}$ emissions were 
reduced during such tests [3]. Thus, the test results did not reflect the emissions occurring during real on-road driving conditions. In addition, and in the aftermath of these revelations, the $\mathrm{CO}_{2}$-emissions have been found to be substantially underreported by many car manufacturers, both for diesel and gasoline cars.

Overall, when set in the context of climate policy requirements, change in the auto-manufacturing sector might be said to be at best incremental. Why is this? Sociotechnical theorists view the active reluctance of an established set of economic interests to change as 'regime resistance' [4]. From a sociotechnical transitions perspective, technological development, science, industry, markets, policy and culture are intertwined, co-evolving in a complex system of mutual interactions [5]. When the auto-industry is so powerful economically, it should not be surprising that economic path dependencies prevail [6].

Here we show the consequences of resisting the need for change, with specific reference to the Dieselgate case. Rather than pursuing electromobility at an earlier date, manufacturers are now left with remediating options that will lead to increases in energy use and emissions of carbon dioxide equivalents, in pursuit of the objective of keeping the emission of nitrogen oxides within regulated standards. We calculate these increases for the several options open to automakers. The calculations take into account several studies that show how manufacturers have also significantly underreported vehicles' actual fuel consumption. We explain our derivation of new factors for energy consumption and greenhouse gas emissions from diesel- and gasoline-powered passenger cars, as well as their electric hybrid varieties.

Our primary research objective is, thus, to provide a quantified estimate of the scale of the unintended climate emissions consequences of one of the most notorious cases of 'regime resistance' in recent times [4]. Following an overview of the policy context, we set out our calculation approach and results.

\section{Policy and Regulatory Context}

In this section we present some of the most salient policy and regulatory context, rather than attempting any form of comprehensive coverage. We first set Dieselgate and related air quality regulation and problems alongside the major challenge posed by stringent climate change targets. With engines based on fossil fuel combustion, these will remain in a degree of conflict and this is the focus of the paper. As the US Environmental Protection Agency has acted with a swiftness unmatched in Europe, imposing fines and effectively costs on VW (in [7] it is claimed that: "U.S. authorities have imposed $\$ 25$ billion in fines, penalties and restitution on VW for the 580,000 tainted diesels it sold in the U.S. In Europe, where the company sold 8 million tainted diesels, VW has not paid a single euro in government penalties."), we also include detail on relevant US legislation breached. We also provide an overview of European Union (EU) policy and legislation relating to $\mathrm{NO}_{\mathrm{x}}$, which incorporates and strengthens internationally applicable World Health Organisation (WHO) guidelines on $\mathrm{NO}_{2}$.

Non-binding, international climate policy is belatedly demanding substantial greenhouse gas (GHG) reductions from all sectors. Remaining within the $+1.5^{\circ} \mathrm{C}$ ambition of the Paris Agreement will be exceedingly challenging and may well require the deployment of carbon removal technologies on a large scale at an early date [8]. Even the less stringent $+2{ }^{\circ} \mathrm{C}$ limit still requires a maximum global atmospheric $\mathrm{CO}_{2}$ concentration of 450 ppmv, preferably 400 ppmv $\mathrm{CO}_{2} .450$ ppmv $\mathrm{CO}_{2}$ requires 3.1-5.7\% annual reductions in total $\mathrm{EU} \mathrm{CO}_{2}$ emissions over the period 2012-2030 (the range reflects alternative climate models) [9]. It should be noted that $450 \mathrm{ppmv} \mathrm{CO}_{2}$ is not a 'safe' concentration: only at levels of around $400 \mathrm{ppmv} \mathrm{CO}_{2}$ equivalent are the risks of overshooting a $2{ }^{\circ} \mathrm{C}$ target low enough that its achievement can be termed "likely" [10]. The $+2{ }^{\circ} \mathrm{C}$ maximum target still requires either that industrialised nations contract carbon emissions immediately, or implies postponed, larger annual decreases that will become increasingly implausible. At the time of writing, we are already at 410 ppmv $\mathrm{CO}_{2}$, i.e., excluding additional GHGs. In short, every tonne of $\mathrm{CO}_{2 \mathrm{eq}}$ counts. 
In contrast, EU transport emissions (for example in terms of geography and including international aviation but excluding international maritime) only started to decrease in 2007 and still remain higher than in 1990, a common benchmark for climate mitigation scenarios. Within transport, road transport is by far the biggest emitter, accounting for more than $70 \%$ of all GHG emissions from transport in 2014 [11]. As we approach 30 years since the first Intergovernmental Panel on Climate Change (IPCC) Scientific Assessment [12], it is difficult to avoid the conclusion that road transport has not been playing an adequate role in GHG emissions reduction.

The situation in terms of local air quality is hardly better. The European Environment Agency (EEA) provides an overview of the European policy context, where air pollution in Europe is persistently above the levels that the WHO considers harmful to human health and where, in 2014, 75,000 people were judged to have died prematurely from $\mathrm{NO}_{x}$ exposure in the EU-28 [13]. A further 399,000 people were judged to have died prematurely in the same year from $\mathrm{PM}_{2.5}$ exposure (ibid.), emitted mainly from diesel road vehicles [14].

The case of Dieselgate reveals how auto-manufacturers have developed techniques (some illegal, some not) to maintain and legitimize particular engine designs. What we show below is that this not only has consequences for the under-estimation of $\mathrm{NO}_{\mathrm{x}}$ emissions, as is now well-known, but that adherence to the broad templates of existing engine designs also has substantial implications for climate-relevant emissions.

European air-quality standards are set by the EU Ambient Air Quality Directives [15] for the protection of human health. The WHO also produces guidelines for $\mathrm{NO}_{2}$. The Ambient Air Quality Directive also sets a critical level for $\mathrm{NO}_{x}$ for the protection of vegetation [15]. Traffic is a major source of $\mathrm{NO}_{2}$ and of $\mathrm{NO}$, which reacts with $\mathrm{O}_{3}$ to form $\mathrm{NO}_{2}$ [13]. The WHO air-quality guideline (AQG) $1 \mathrm{~h}$ value for $\mathrm{NO}_{2}$ is 200 micrograms per $\mathrm{m}^{3}$ of air and the calendar year average guideline is 40 micrograms. The limit values in the EU Ambient Air Quality Directives (a list of relevant EU legislation is available here: $\mathrm{http}$ // / ec.europa.eu/environment/air/quality/existing_leg.htm) are the same, but the $1 \mathrm{~h}$ limit is not to be exceeded on more than $18 \mathrm{~h}$ per year and there is an alert threshold of $400 \mu \mathrm{g} / \mathrm{m}^{3}$ to be measured over 3 consecutive hours over $100 \mathrm{~km}^{2}$ or an entire 'zone' [13].

In Europe, the above regulations are intended to help achieve the 2030 objectives of the Clean Air Programme, central to which is Directive 2016/2284/EU on the reduction of national emissions of certain atmospheric pollutants. This directive sets national reduction commitments for five atmospheric pollutants that include $\mathrm{NO}_{\mathrm{x}}$. The new directive repeals and replaces Directive 2001/81/EC, the National Emission Ceilings Directive (NEC Directive) from the date of its transposition (30 June 2018), and is intended to ensure that the emission limits for 2010 set in that directive shall apply until 2020. Directive 2016/2284 also transposes the reduction commitments for 2020 taken by the EU and its member states under the revised Gothenburg Protocol and sets more ambitious reduction commitments for 2030 so as to cut the health impacts of air pollution by half compared with 2005.

Rather than rehearse relevant US air quality legislation, in Figure 1 we cite the very specific regulations pertaining to the Dieselgate case. 
The following summary was extracted directly from the US EPA website on 16 May 2018.

\section{Defeat Devices}

Section 203 (a)(3)(b) of the Clean Air Act (CAA), 42 U.S.C. Section 7522(a)(3)(b), prohibits the manufacture, selling, or installation of any device that intentionally circumvents EPA emission standards by bypassing, defeating, or rendering inoperative a required element of the vehicle's emissions control system.

Section 203 (a)(1) of the same Act also prohibits the sale of motor vehicles or engines that are not covered by valid certificates of conformity.

40 CFR Part 86, Subpart A contains the regulatory language pertaining to defeat devices. Section 86.1803-01 defines Auxiliary Emission Control Devices (AECDs) and defeat devices Section 86.1809-12 sets forth the prohibition of defeat devices

\section{Recall}

EPA has the authority under Section 207(c)(1) of the CAA to require a manufacturer to issue a recall when EPA determines that a substantial number of vehicles do not conform to EPA regulations. Section 203(a)(4)(B) of the CAA makes clear that it is a prohibited act for manufacturers to fail or refuse to comply with an ordered recall by EPA.

40 CFR Part 85 Subpart S contains the regulations (40 CFR 85.1801-85.1808) regarding recall requirements for light-duty vehicles.

\section{U.S. NOx Emission Standards for Light Duty Cars and Trucks}

EPA has introduced progressively more stringent light-duty vehicle emission standards since the 1970 CAA established the agency and its authority to regulate pollution from motor vehicles. EPA's Tier 1 emission standards were in effect from the mid-1990s through the mid-2000s before being replaced by EPA's Tier 2 standards which began phasing in with the 2004 model year. The Volkswagen vehicles listed in the Notice of Violation were subject to the Tier 2 emission standards. The most recent stringency increase was promulgated with the Tier 3 regulations, which take effect starting in model year 2017.

Figure 1. US EPA Laws and Regulations related to Volkswagen Violations [16].

\section{Methods}

This article presents the calculations performed and the results obtained for adjusting factors for energy use and climate change gas emissions present in a database developed by VESTFORSK. In this article the database is referred to as the "VF-database". It is accessible at http:/ / transport.vestforsk.no/ and contains factors for various forms of transport in Norway. The documentation and references to the background studies for the factors are available at the same web site.

Trips by vehicles are categorised as either short or long, with long trips extending more than $100 \mathrm{~km}$. This is a common division in Norway, established by Institute of Transport 
Economics [17]. The occupancy rate (persons per car) used is 2.0 for long trips and 1.3 for short trips [18]. All calculations performed are shown in the appended Excel sheets, as Supplementary Materials attached to the paper, so that readers of the manuscript can access them.

\section{The Dieselgate Scandal}

On 18 September 2015, the US EPA announced that Volkswagen Group (VWG) was breaching its federal emissions legislation by fitting illegal software (defeat device) to cheat emissions tests [19]. VW admitted that a cheating program was installed in cars with 4-cylinder and 2.0-L diesel engine [20]. These cars included VW Jetta (Year 2009-2015), VW Beetle (Year 2009-2015), Audi A3 (Year 2009-2015), VW Golf (Year 2009-2015), VW Passat (Year 2014-2015) and unspecified models of Skoda. Among the cars that had this cheating software installed were as many as 482,000 cars sold in the United States. The background to the scandal was that in a US study, significantly higher $\mathrm{NO}_{\mathrm{x}}$ emissions were measured while driving than the US standard US EPA Tier 2 Bin 5 implies [21]. The emissions were 15-35 times higher for the VW Jetta and 5-20 times higher for the VW Passat [22]. Emissions from the BMW X5 were also measured and were on average lower than the standard, but exceeded the standard on some uphill sections.

The list of diesel car producers that have cars exceeding the emissions standards for $\mathrm{NO}_{\mathrm{x}}$ has gradually increased and later came to include Mercedes-Benz, Honda, Mazda and Mitsubishi. In tests performed by the UK based company Emissions Analytics, the $\mathrm{NO}_{x}$ emissions from some Honda diesel car models were measured to exceed the emission limit by a factor of six [23]. In some four-wheel drive models, it was as high as 20 times the limit.

New diesel cars from Renault, Nissan, Hyundai, Citroen, Fiat, Jeep and Volvo have also been found to emit considerably more $\mathrm{NO}_{\mathrm{x}}$ than indicated on the declarations from the automakers [24]. The tests were conducted by the German organisation Allgemeiner Deutscher Automobil-Club (ADAC), and the results showed that some of the car models had $\mathrm{NO}_{\mathrm{x}}$ emissions that exceeded the specified level by a factor of 10. The largest deviations were found in Renault Espace Energy dCi 160, which had 11 times the emissions stated by the manufacturer. The Jeep Renegade 2.0 emitted 10 times the level stated by the manufacturer, while Hyundai i20-1.1, Fiat 500x, Citroen DS5-Hybrid 4, all had $\mathrm{NO}_{\mathrm{x}}$ emissions that exceeded the stated emissions levels by 6 times (ibid.).

Dieselgate is thus not just a VW problem, but an industry-wide one. A report by an independent French commission showed that out of 86 Euro 5 and Euro 6 diesel cars that were tested during driving, only $20 \%$ did not substantially exceed the declared $\mathrm{NO}_{x}$ emission [25]. The model that exceeded the most was Fiat 500x, which had an emission of $1354 \mathrm{mg} / \mathrm{km}$, compared to the declared value of $68 \mathrm{mg} / \mathrm{km}$, and was thus almost 20 times as high. Other cars that came out very badly in that study included several models of Renault (Talisman, Kadjar, Captur and Espace), Nissan Qashqai, Mercedes B-Class, Opel Mokka, Opel Zafira, Alfa Romeo Giulietta and Ford C-Max (ibid.).

The seriousness of the emission exceedances is enhanced by the fact that one year after the original disclosure of the scandal, a survey of 230 diesel models showed that all major diesel car producers sell cars with $\mathrm{NO}_{\mathrm{x}}$ emissions equal to, or larger than, the corresponding emissions from $\mathrm{VW}$ models [19]. The emissions from Fiat and Suzuki diesel cars averaged 15 times more than the legal EU limit for $\mathrm{NO}_{\mathrm{x}}$, while the results for Renault-Nissan vehicles were 14 times more than the limit and Opel/Vauxhall 10 times more than the limit. Volkswagen diesel cars polluted "only" twice as much as Euro 6 standard [26]. Ironically, then, VW diesel cars are relatively clean.

If the car manufacturers can reduce $\mathrm{NO}_{\mathrm{x}}$ emissions to comply with emissions standards, also during actual driving, a crucial question to answer is: how will this affect fuel consumption and consequently $\mathrm{CO}_{2}$ emissions? A key prerequisite for answering this is knowledge of the magnitude of the errors in the data supplied by car manufacturers. For this reason, the effect of $\mathrm{NO}_{\mathrm{x}}$-reducing measures and errors in the stated figures for fuel consumption and $\mathrm{CO}_{2}$ emissions have both been incorporated in the updated factors for energy use and emissions in the VF-database, the relevant database for energy and emissions developed by Vestlandsforsking and that we apply here. 


\section{The Technologies for Reducing $\mathrm{NO}_{x}$ Emissions}

Air is essentially a mixture of molecular nitrogen $\left(\mathrm{N}_{2}\right)$ and oxygen $\left(\mathrm{O}_{2}\right)$. When the mixture of air and fuel is combusted, in those areas of the combustion chamber where the temperature is high enough (above $1500^{\circ} \mathrm{C}$ ), a reaction occurs where some of the molecular nitrogen becomes oxidized to $\mathrm{NO}_{x}$ gases [27]. A gasoline engine operates at a somewhat lower temperature than a diesel engine, and achieves less often the critical temperature for $\mathrm{NO}_{\mathrm{x}}$ formation. This results in lower $\mathrm{NO}_{\mathrm{x}}$ emissions from gasoline engines. The reason why the temperature inside a diesel engine is higher is that the diesel is compressed to achieve self-ignition, and this compression emits much heat. In a gasoline engine, a spark plug is applied to achieve the ignition, and thus a high degree of compression is not required, hence the lower combustion temperature.

High $\mathrm{NO}_{\mathrm{x}}$ emissions occur at driving patterns that are demanding for the engine, such as during rapid acceleration or driving in steep uphills. Such driving increases the temperature of the engine, resulting in increased amount of $\mathrm{NO}_{\mathrm{x}}$ being formed and emitted [28].

In this article, three main types of technologies for reducing emissions of $\mathrm{NO}_{\mathrm{x}}$ are considered. They are exhaust-gas recycling (EGR), selective catalytic reduction (SCR), and lean $\mathrm{NO}_{\mathrm{x}}$ trap (LNT). They are discussed in detail below, in order for the reader to comprehend the principles behind why and how each of the technologies contribute towards increased fuel consumption. The key characteristics, as well as similarities and differences between these technologies are shown in Table 1 .

Table 1. Key characteristics and similarities of main $\mathrm{NO}_{\mathrm{x}}$ reducing technologies.

\begin{tabular}{cccc}
\hline Technology & Application & $\begin{array}{c}\text { Working Principle for } \\
\text { Reducing } \mathrm{NO}_{\mathbf{x}}\end{array}$ & $\begin{array}{c}\text { Why Increased } \mathrm{CO}_{2} \\
\text { Emissions? }\end{array}$ \\
\hline $\begin{array}{c}\text { Exhaust-gas } \\
\text { recycling (EGR) }\end{array}$ & Passenger cars & Reduced combustion temperature & Lower engine efficiency \\
\hline $\begin{array}{c}\text { Selective catalytic } \\
\text { reduction (SCR) }\end{array}$ & $\begin{array}{c}\text { Heavy duty vehicles } \\
\text { (mainly) }\end{array}$ & $\begin{array}{c}\text { Urea additive facilitates catalytic } \\
\text { conversion of } \mathrm{NO}_{\mathrm{x}} \text { to } \mathrm{N}_{2}\end{array}$ & $\begin{array}{c}\text { Urea production and } \\
\text { consumption }\end{array}$ \\
\hline Lean $\mathrm{NO}_{\mathrm{x}}$ trap (LNT) & Passenger cars & $\begin{array}{c}\text { Physical adsorption of } \mathrm{NO}_{x} \text { with } \\
\text { regeneration to } \mathrm{N}_{2}\end{array}$ & $\begin{array}{c}\text { Regeneration with high } \\
\text { fuel content }\end{array}$ \\
\hline
\end{tabular}

\subsection{Exhaust Gas Recycling (EGR)}

In EGR, a fraction of the exhaust volume is diverted ("recycled") back to the air intake manifold, where it is mixed into the air that enters the combustion chamber. The amount of this oxygen-poor exhaust being returned can be varied by an electronically controlled valve. When some of the oxygen-rich intake air is replaced with oxygen-poor exhaust, the lower total oxygen content in the combustion chamber results in fewer available oxygen molecules per volume of air, and thus less frequent combustion of the hydrocarbon molecules. The result is that the combustion process emits less heat, so that the temperature becomes lower, thus reducing $\mathrm{NO}_{\mathrm{x}}$ emissions. However, when the temperature drops, the engine is converting less chemical energy to mechanical energy and this less-efficient combustion of the fuels has been judged to result in $20-30 \%$ increased emissions of unburned hydrocarbons [29].

It has been reported as possible to keep the resulting increase in diesel consumption from this to below $5 \%$, by the application of stringent manipulation of the fuel-injection control parameters [30]. US regulations on the use of EGR led to a 3\% reduction in energy efficiency for heavy duty vehicles [31]. To reduce $\mathrm{NO}_{\mathrm{x}}$ emissions from passenger cars in Europe, EGR is one of the main technologies used. However, this technology does not work at high engine loads, such as above 50-75\% [32].

\subsection{Selective Catalytic Reduction (SCR)}

The second main technology for $\mathrm{NO}_{\mathrm{x}}$ reduction is selective catalytic reduction (SCR). This involves the use of a reducing agent in a diesel exhaust fluid (DEF), known under the trademark AdBlue in 
Europe. In both cases, it is a mixture of urea in water. When this mixture is injected into the catalyst, $\mathrm{NO}_{\mathrm{x}}$ is converted to nitrogen gas $\left(\mathrm{N}_{2}\right)$ and water. In Europe, this strategy has until recently mainly been reserved for heavier vehicles and some larger passenger cars, while it is often used also on smaller passenger cars in the United States.

\subsection{Lean-NO $\mathrm{Trap}_{\text {(LNT) }}$}

A third $\mathrm{NO}_{\mathrm{x}}$-reduction technology is the so-called lean- $\mathrm{NO}_{\mathrm{x}}$ trap (LNT). The trap has absorbent material on the surfaces, which exhaust and $\mathrm{NO}_{2}$ attach to. When there is no space for more $\mathrm{NO}$ and $\mathrm{NO}_{2}$ on the surface of the absorbent material, the absorbed molecules must be removed so that surface space is made available for more $\mathrm{NO}$ and $\mathrm{NO}_{2}$ to be trapped. This regeneration is carried out by significantly increasing the diesel content in the diesel-air mixture, and the surplus of diesel causes un-combusted hydrocarbons $(\mathrm{HC})$ to react with $\mathrm{NO}$ and $\mathrm{NO}_{2}$ that is bound to the trap. This reaction converts $\mathrm{NO}$ and $\mathrm{NO}_{2}$ to $\mathrm{N}_{2}, \mathrm{CO}_{2}$ and $\mathrm{H}_{2} \mathrm{O}$. The use of such after-injection of fuel does imply an increase in the total fuel consumption of the vehicle [33]. That this technology does not always work well is illustrated by the results of the US measurement of real-world emissions of $\mathrm{NO}_{\mathrm{x}}$, where one of the cars (VW Jetta turbo diesel injection (TDI)) had an LNT installed, but still exceeded the US EPA Tier 2-Bin 5 standard by 15 to 35 times [22].

\subsection{Other $\mathrm{NO}_{x}$-Reducing Technologies}

There are also other technologies for reducing $\mathrm{NO}_{x}$ emissions. For example, several additives can be used, but they are not considered to work well enough to make significant contributions to the reduction of $\mathrm{NO}_{\mathrm{x}}$ emissions [29]. Delayed injection may also be effective in reducing $\mathrm{NO}_{\mathbf{x}}$, but this significantly increases the fuel consumption, so it is not considered likely that car manufacturers will introduce this on large scale (ibid.). Injection of water and the use of fuel consisting of an emulsion mixture of water and diesel can be effective in reducing $\mathrm{NO}_{\mathrm{x}}$ emissions, but this increases the risk of corrosion of important engine components and thus is also not expected to be implemented (ibid.).

As these other strategies for reducing emissions of $\mathrm{NO}_{\mathrm{x}}$ are of little relevance, we are left with the three main technologies; exhaust gas recirculation (EGR), selective catalytic reduction (SCR) and lean- $\mathrm{NO}_{\mathrm{x}}$ trap (LNT), which in the following section are assessed in terms of how they each contribute to the adjustment of the factors in the VF-database.

\section{Calculations of the Contributions of the $\mathrm{NO}_{x}$-Reducing Technologies to Increased Energy Use and Climate Gas Emissions}

In this section we show how the three main technologies for reducing $\mathrm{NO}_{\mathrm{x}}$ each contribute to increased factors for energy use and climate gas emissions.

\subsection{Contribution from Adjustments in Exhaust-Gas Recirculation}

To calculate the size of the increase in fuel consumption and $\mathrm{CO}_{2}$ emissions that can be expected from $\mathrm{NO}_{\mathrm{x}}$ emission reductions, we start with the assumption that-as $\mathrm{VW}$ stated with respect to its vehicles in the US - all cars affected by the emissions measurement cheating would have updated computer software and retrofit equipment installed [34]. Hence a VW recall procedure for affected cars in Europe began in January 2016 [35,36] and the measure for the cars with EA189 engine in sizes 1.2 and $2.0 \mathrm{~L}$ was a software update only. In addition to this software update, cars with a $1.6 \mathrm{~L}$ engine also would have installed a so-called "flow straightener". This consists of a grid that is placed directly in front of the air flow meter before the intake manifold. The purpose of the flow straightener is to obtain a more precise measurement of the air flow so that the EGR system can increase more precisely the amount of recirculated exhaust, thereby better measuring the reductions in $\mathrm{NO}_{\mathrm{x}}$ emissions. However, increased exhaust circulation has been reported to cause more soot formation, resulting in increased need for maintenance of the engine [37]. The recirculated exhaust contains incompletely combusted fuel and combustion compounds that with time form deposits on the EGR valve. These deposits 
increase the tendency of the valve to not close completely, even if the electronic control tries to make it close. The increased amount of exhaust recirculation thus increases the risk of such valve fouling occurring. When the valve is left in a partially open position, exhaust enters the intake manifold when this is not supposed not occur, in accordance with the electronic control. This phenomenon leads to increased fuel consumption [38].

It can be assumed that in the case of both car models that were previously fitted with the cheating software, and those with the 1.6 L EA 189 engine that in addition are given an air flow straightener, more of the exhaust gas will be recirculated to reduce $\mathrm{NO}_{x}$ emissions while driving. However, it can also be assumed that the occurrence of deposits leading to unwanted leakage will also increase and that this will result in increased consumption of fuel. In June 2016, Volkswagen announced that the software update had also begun for other car models with the 2.0 L type EA189 TDI engine, namely several Audi models (A4, A5, A6 and Q5) and Seat Exeo [39].

Tests also show that the engine produces less power, measured in terms of a lower maximum torque, when in cheating mode in a test laboratory: for a VW Jetta TDI, the difference was $43.4 \mathrm{Nm}$ [34]. This correlates to a $12 \%$ reduction in engine power, from $352.5 \mathrm{Nm}(260 \mathrm{lb}-\mathrm{ft})$ measured at $2.561 \mathrm{rpm}$ down to $309.1 \mathrm{Nm}(228 \mathrm{lb}-\mathrm{ft})$ measured at $2.588 \mathrm{rpm}$. The expected technical changes described above are thus likely to result in lower torque, allowing engines to "slow down" and to not respond as quickly as before to gas (accelerator) pedal pressure [32].

One of the car models that had been given an upgrade of the software was tested by the German car magazine "Auto Motor und Sport" to find out how much the software upgrade affected fuel consumption [40]. This was on a Volkswagen Amarok, which was the first model that had its cheating program removed. The result for the two cars tested was that fuel consumption increased from $0.82 \mathrm{~L}$ per $10 \mathrm{~km}$ before the software upgrade, to 0.89 and $0.87 \mathrm{~L}$ per $10 \mathrm{~km}$ after. This translates into an increase of $8.5 \%$ and $6.1 \%$ for each of the two cars, respectively.

The investigation carried out by the German Federal Motor Transport Authorities showed that the producers of EGR control systems used in several car models, have designed the exhaust recirculation system to be disabled when the ambient temperature drops below a certain low limit [41]. This is conducted, according to the German AutoEvolution car magazine, to extend the life of the EGR system [42]. In the investigation, it was determined that the EGR system was partially or completely disabled at temperatures lower than $+17^{\circ} \mathrm{C}$ for several models of Opel and Renault-Nissan, while in Daimler and Mercedes models this occurred at temperatures below $+10{ }^{\circ} \mathrm{C}$. For Peugeot 308 1.6 L, the EGR system switched off at temperatures below $+5{ }^{\circ} \mathrm{C}$. In some models of Fiat and Ford, the EGR system turned off also when the vehicle was fully loaded or was running at high speed. The Kraftfahrt-Bundesamt (KBA) test showed that only 10 of the 53 cars tested complied with the $\mathrm{NO}_{\mathrm{x}}$ emission requirements at $-10^{\circ} \mathrm{C}$. In some models of Fiat, the EGR system was deactivated after the engine had been running for $22 \mathrm{~min}$, to trick the New European Driving Cycle (NEDC) test, which is usually only run for $20 \mathrm{~min}[43,44]$.

Based on the accumulated knowledge presented above, we suggest that it is empirically justifiable to estimate that a $7 \%$ increase in fuel consumption will result from the EGR adjustments that the car manufacturers are expected to implement (See Table 2).

Table 2. Summary of additions to factors for energy consumption per vehicle kilometre of passenger cars.

\begin{tabular}{ccc}
\hline & Calculation Method & Addition of Energy (MJ) \\
\hline & Contribution from adjusted EGR: & \\
Tank-to-wheel (TtW) Diesel & $7.0 \%$ of $1.66 \mathrm{MJ}$ & 0.12 \\
TtW Hybrid-diesel & $7.0 \%$ of $1.33 \mathrm{MJ}$ & 0.09 \\
\hline & Contribution from SCR: & \\
Well-to-tank (WtT) Diesel & $31.4 \%$ of $0.27 \mathrm{MJ}$ & 0.08 \\
WtT Hybrid-diesel & $31.4 \%$ of $0.21 \mathrm{MJ}$ & 0.07 \\
TtW Diesel & $0.7 \%$ of $1.66 \mathrm{MJ}$ & 0.01 \\
TtW Hybrid-diesel & $0.7 \%$ of $1.33 \mathrm{MJ}$ & 0.01 \\
\hline
\end{tabular}


Table 2. Cont.

\begin{tabular}{ccc}
\hline & Calculation Method & Addition of Energy (MJ) \\
\hline TtW Diesel & Contribution from LNT: & \\
TtW Hybrid-diesel & $3.0 \%$ of 1.66 MJ & 0.05 \\
Contribution from discrepancy between stated and real consumption: & 0.04 \\
TtW Diesel & $3.0 \%$ of $1.33 \mathrm{MJ}$ & 0.23 \\
TtW Gasoline & $14.0 \%$ of $1.66 \mathrm{MJ}$ & 0.26 \\
TtW Hybrid-diesel & $14.0 \%$ of $1.88 \mathrm{MJ}$ & 0.19 \\
TtW Hybrid-gasoline & $14.0 \%$ of $1.33 \mathrm{MJ}$ & 0.22 \\
\hline Sum of additions to single segments of the energy chain: & \\
TtW Diesel & $14.0 \%$ of 1.54 MJ & 0.41 \\
TtW Gasoline & 0.26 \\
TtW Hybrid-diesel & 0.33 \\
TtW Hybrid-gasoline & 0.22 \\
WtT Diesel & 0.09 \\
WtT Hybrid-diesel & 0.07 \\
Sum of additions in all segments of energy chain $(\mathrm{WtT}+\mathrm{TtW}):$ \\
Diesel & 0.50 \\
Gasoline & 0.26 \\
Hybrid-diesel & 0.40 \\
Hybrid-gasoline & 0.22 \\
\hline
\end{tabular}

\subsection{Contribution from the Use of Selective Catalytic Reduction in Passenger Cars}

Increased consumption of diesel exhaust fluid/AdBlue in those cars that have already installed SCR could result from the changes that are likely to be made to reduce on-road $\mathrm{NO}_{\mathrm{x}}$ emissions. It is in addition also expected that SCR systems will be retrofitted on cars that do not already have this installed. Most importantly, a growing number of new diesel passenger cars will be delivered complete with SCR technology installed [45].

In the scenario in which new diesel cars in Europe are equipped with SCR, the production and consumption of AdBlue must be included in the calculation of total $\mathrm{CO}_{2}$ emissions from the vehicles. Knowledge of the consumption of AdBlue in heavy-duty vehicles can be a basis for the calculation of the consumption in passenger cars. Volvo states that the AdBlue consumption in lorries is in the order of $4-8 \%$ of the diesel consumed, depending on the Euro class and model [46]. An AdBlue consumption of $4.1 \%$ is used in a Spanish study [47]. In [45] it is pointed out that AdBlue consumption will increase in line with stricter emission requirements, from $5 \%$ for Euro 5 to $10 \%$ for Euro 6 vehicles.

The energy consumption in the production of AdBlue can be calculated from available data on the production of urea. It has been determined that $51.6 \mathrm{MJ}$ is consumed per $\mathrm{kg}$ nitrogen in production of urea [48]. Since the nitrogen content in urea is $46.6 \%$, this translates into an energy consumption of $110.68 \mathrm{MJ}$ per $\mathrm{kg}$ of urea. AdBlue is a solution of $32.5 \%(w / w)$ urea in water, so $35.8 \mathrm{MJ}$ are consumed to produce $1 \mathrm{~kg}$ of AdBlue. With an estimated consumption of AdBlue equal to 6\% of the diesel consumption, the AdBlue consumption implies an additional $2.16 \mathrm{MJ}$ per $\mathrm{kg}$ of diesel consumed. The density of diesel is $0.83 \mathrm{~kg} / \mathrm{L}$, so the AdBlue consumption equals $1.79 \mathrm{MJ}$ per litre of diesel consumed.

The VF-database has a factor for the consumption of diesel for passenger cars of $1.66 \mathrm{MJ}$ per vehicle-kilometre (vkm), which with an energy content of $35.11 \mathrm{MJ}$ per litre of diesel equals $0.047 \mathrm{~L}$ per vkm. Thus, the consumption of AdBlue at 1.79 MJ per litre of diesel consumed amounts to an additional $0.085 \mathrm{MJ}$ per vkm. In the VF-database, the factor for well-to-tank (WtT) energy consumption for diesel passenger car is $0.27 \mathrm{MJ}$ per vkm, so AdBlue consumption constitutes an addition of $31.4 \%$ to the well-to-tank factor, as shown in Table 2.

There is also tank-to-wheel ( $\mathrm{TtW}$ ) contribution from the consumption of AdBlue, as the carbon in urea ends up as $\mathrm{CO}_{2}$ in the exhaust. An estimated AdBlue consumption of $6 \%$ of diesel consumption of $1.66 \mathrm{MJ} / \mathrm{vkm}$ implies a consumption of $0.0028 \mathrm{~L}$ of AdBlue per vkm. When we again consider 
that AdBlue consists of $32.5 \%(w / w)$ urea, $0.00092 \mathrm{~L}$ of urea per vkm is consumed. Urea has a density of $1.32 \mathrm{~kg}$ per litre. Thus, it is consumed $1.217 \mathrm{~g}$ of urea per vkm. As urea contains $19.98 \%$ carbon, this consumption thus constitutes carbon emissions of $0.243 \mathrm{~g}$ of carbon per vkm. Taking into consideration the fact that $3.67 \mathrm{~g}$ of $\mathrm{CO}_{2}$ is formed from $1 \mathrm{~g}$ of carbon, the result is that AdBlue contributes to increased tank-to-wheel emissions of $0.892 \mathrm{~g}$ of $\mathrm{CO}_{2}$ per vkm. The VF database has a tank-to-wheel factor for emissions of $123.1 \mathrm{~g}$ of $\mathrm{CO}_{2}$ equivalents per vkm for diesel passenger cars. The emission from AdBlue consumption thus adds a tank-to-wheel addition of $0.7 \%$, as shown in Table 2 .

\subsection{Contribution from the Use of Lean-NOx Trap (LNT)}

Based on information given to the author (pers. comm. from experts who prefer to be un-named, in the field of emissions measurements), it is justifiable to estimate an increase in fuel consumption by $3 \%$ from increased frequency for post-injection for lean- $\mathrm{NO}_{\mathrm{x}}$ trap regeneration, as we show in Table 2. The production of lean- $\mathrm{NO}_{\mathrm{x}}$ trap should preferably also be included in the calculation, but the necessary data is not available for this.

\section{How Reported Discrepancies between Stated and Actual Fuel Consumption Contribute to Changing the Database Factors}

In this section, we show how deviations between consumption during real-life driving and that reported by car manufacturers are considered when updating the factors contained in the VF-database. In 2015, Volkswagen announced that real-life fuel consumption and $\mathrm{CO}_{2}$ emissions, in addition to $\mathrm{NO}_{x}$ emissions, are higher than previously stated [49-51]. The reference to higher $\mathrm{CO}_{2}$ emissions applied to both diesel and gasoline cars, but is particularly so for diesel cars. Under consideration were nine different car models, which were stated on average to consume $0.1-0.2 \mathrm{~L}$ extra fuel per $100 \mathrm{~km}$ [52]. Using the average value of $0.15 \mathrm{~L}$ and diesel density of 0.83 and that $1 \mathrm{~kg}$ of diesel gives rise to $3.15 \mathrm{~kg}$ of $\mathrm{CO}_{2}$, it is possible to calculate an addition of $3.9 \mathrm{~g} \mathrm{CO}_{2}$ per vkm. For the stated $\mathrm{CO}_{2}$ emission figure for the average of new cars in 2014, of $123 \mathrm{~g}$ per vkm [53], this stated correction equals an additional amount of $3.2 \%$.

The French IFPEN study showed that $\mathrm{CO}_{2}$ emissions from a high number of car models were significantly higher than that stated by the manufacturers. On average, 89 different car models released 29.3\% more $\mathrm{CO}_{2}$ than stated [25]. The EQUA Fuel Economy Index, developed by the British company Emission Analytics, contains test results for more than 800 vehicles, for which is estimated for the year 2016 a real average fuel consumption of diesel cars 35.1\% higher than the stated consumption. Corresponding deviations for gasoline cars are estimated to average $27.1 \%$, and $50.6 \%$ for hybrid gasoline cars [54].

Official average $\mathrm{CO}_{2}$ emissions from new cars in Europe have been reduced from 170 to $123 \mathrm{~g} / \mathrm{vkm}$ in the years 2001-2014 [53]. During these years, the reduction has gradually increased from year to year, from approx. $1 \%$ per year to approx. $4 \%$ annual reduction. However, the International Council on Clean Transportation (ICCT) has concluded that the difference between actual and stated $\mathrm{CO}_{2}$ emissions for gasoline and diesel cars has risen significantly, from 8\% in 2001 to $40 \%$ in 2014 [28].

In the VF-database, the factors for tank-to-wheel $\mathrm{CO}_{2 \text { eq }}$ emissions per vkm from passenger cars in Norway in 2010 are estimated at $123.1 \mathrm{~g}$ and $138.8 \mathrm{~g}$ for diesel and gasoline, respectively. The corresponding factors for hybrid cars are $99.1 \mathrm{~g}$ and $114.0 \mathrm{~g}$, respectively, for diesel and gasoline. These factors are from Concawe/Eucar, obtained by simulating the driving cycle NEDC, and not from empirical testing [55]. This is the test cycle that car manufacturers base their reporting on, and it is these factors that in this article are adjusted reflecting emissions under real driving conditions.

The reduction in official $\mathrm{CO}_{2}$ emissions for new cars in Norway has followed a trend similar to that which [53] reports, i.e., gradual change from $1 \%$ per year to approx. $4 \%$ annually over the years 2001-2014. Given this it can be calculated that the 2010 factor of $123.1 \mathrm{~g}$ corresponds to $108.4 \mathrm{~g}$ in 2014. Empirically generated emission figures are not available for diesel and gasoline cars in Norway without the inclusion of hybrids in the statistics, so estimation is necessary. We do this by assuming an 
annual reduction of $4 \%$ from 2014 to 2016, thus $\mathrm{CO}_{2}$ emissions can be estimated to be $99.9 \mathrm{~g}$ per vkm for diesel cars in 2016. Real emissions can then be estimated to be $40 \%$ higher [28], i.e., $139.8 \mathrm{~g}$ per vkm. Similarly, for gasoline cars, $157.7 \mathrm{~g}$, for hybrid cars $112.6 \mathrm{~g}$ and $129.5 \mathrm{~g}$ respectively for diesel and gasoline hybrid. The 2010 factors for tank-to-wheel energy use in the database thus obtain an addition of $14 \%$, as shown in Table 2.

\section{Results of the Analysis}

When the impact of $\mathrm{NO}_{\mathrm{x}}$ reducing measures and the deviation between real-life and stated consumption and $\mathrm{CO}_{2}$ emissions from passenger cars are summarized, the factors for energy consumption per vehicle kilometre in the VF-database can be adjusted as shown in Table 2.

Changes in $\mathrm{CO}_{2 \text { eq }}$ emissions are calculated from the energy consumption additions in Table 2 using a $\mathrm{CO}_{2}$ content of $3.15 \mathrm{~kg}$ per $\mathrm{kg}$ of fuel and an energy content of 42.3 and $44.0 \mathrm{MJ}$ per $\mathrm{kg}$ of fuel for diesel and gasoline, respectively. However, this gives an underestimation of $\mathrm{CO}_{2 \mathrm{eq}}$ emissions, as it is based on $\mathrm{CO}_{2}$ only. The other emission components that contribute to the total $\mathrm{CO}_{2 e q}$ emissions must also be included. For exhaust emissions from diesel and gasoline cars, these other emissions are mainly methane $\left(\mathrm{CH}_{4}\right)$ and nitrous oxide $\left(\mathrm{N}_{2} \mathrm{O}\right)$. The contribution from these other greenhouse gases can be included in the calculations by considering that when one $\mathrm{kg} \mathrm{CO}_{2}$ is emitted from diesel cars, also $0.0054 \mathrm{~g}$ of $\mathrm{CH}_{4}$ are emitted, when using the value for 2013 [56]. The corresponding value for $\mathrm{N}_{2} \mathrm{O}$ is $0.0285 \mathrm{~g}$ (ibid.). For gasoline cars, the factors are $0.1331 \mathrm{~g} \mathrm{CH}_{4}$ and $0.0156 \mathrm{~g} \mathrm{~N}_{2} \mathrm{O}$. GWP100 is 34 and 298 for $\mathrm{CH}_{4}$ and $\mathrm{N}_{2} \mathrm{O}$, respectively, so that each gram of $\mathrm{CH}_{4}$ gives a contribution of $34 \mathrm{~g} \mathrm{CO}_{2 e q}$, while

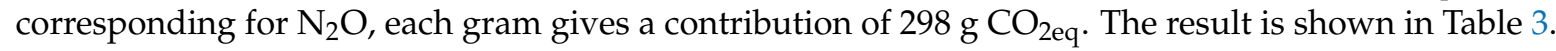

Table 3. Additional factors for $\mathrm{CO}_{2 \mathrm{eq}}$ emissions per vehicle kilometre.

\begin{tabular}{|c|c|c|c|c|}
\hline & \multicolumn{4}{|c|}{ Addition (gram $\mathrm{CO}_{2 \mathrm{eq}}$ ) } \\
\hline & $\mathrm{CO}_{2}$ & $\mathrm{CH}_{4}$ & $\mathrm{~N}_{2} \mathrm{O}$ & Sum \\
\hline TtW Diesel & 30.56 & 0.01 & 0.26 & 30.82 \\
\hline TtW Gasoline & 18.84 & 0.09 & 0.09 & 19.02 \\
\hline TtW Hybrid-diesel & 24.48 & 0.00 & 0.21 & 24.70 \\
\hline TtW Hybrid-gasoline & 15.44 & 0.07 & 0.07 & 15.58 \\
\hline WtT Diesel & 6.31 & 0.00 & 0.05 & 6.37 \\
\hline WtT Hybrid-diesel & 4.91 & 0.00 & 0.04 & 4.95 \\
\hline \multicolumn{5}{|c|}{ Sum TtW + WtT: } \\
\hline Diesel & 36.87 & 0.01 & 0.31 & 37.19 \\
\hline Gasoline & 18.84 & 0.09 & 0.09 & 19.02 \\
\hline Hybrid-diesel & 29.39 & 0.01 & 0.25 & 29.65 \\
\hline Hybrid-gasoline & 15.44 & 0.07 & 0.07 & 15.58 \\
\hline
\end{tabular}

By using the existing ("old") factors in the VF-database for WtT of gasoline cars and WtT of hybrid gasoline vehicles, as well as infrastructure and fabrication of vehicles of for all car types, new factors are elucidated and shown together with the old factors in Table 4.

Table 4. Compilation of new and old factors for energy consumption and $\mathrm{CO}_{2 \mathrm{eq}}$ emissions per vehicle kilometre.

\begin{tabular}{cllcccc}
\hline & \multicolumn{3}{l}{ Energy (MJ) } & \multicolumn{3}{c}{ CO $_{2 \text { eq }}$ (gram) } \\
\hline & Old & New & Diff. & Old & New & Diff. \\
\hline TtW Diesel & 1.66 & 2.07 & $+25 \%$ & 123.10 & 153.92 & $+25 \%$ \\
TtW Gasoline & 1.88 & 2.14 & $+14 \%$ & 138.80 & 157.82 & $+14 \%$ \\
TtW Hybrid-diesel & 1.33 & 1.66 & $+25 \%$ & 99.10 & 123.80 & $+25 \%$ \\
TtW Hybrid- gasoline & 1.54 & 1.76 & $+14 \%$ & 114.00 & 129.58 & $+14 \%$ \\
WtT Diesel & 0.27 & 0.35 & $+30 \%$ & 23.50 & 29.87 & $+27 \%$ \\
WtT Hybrid-diesel & 0.21 & 0.28 & $+33 \%$ & 18.90 & 23.85 & $+26 \%$ \\
\hline
\end{tabular}


Table 4. Cont.

\begin{tabular}{|c|c|c|c|c|c|c|}
\hline & \multicolumn{3}{|c|}{ Energy (MJ) } & \multicolumn{3}{|c|}{$\mathrm{CO}_{2 \text { eq }}$ (gram) } \\
\hline & Old & New & Diff. & Old & New & Diff. \\
\hline \multicolumn{7}{|c|}{ Sum TtW + WtT: } \\
\hline Diesel & 2.56 & 3.06 & $+20 \%$ & 180.50 & 217.69 & $+21 \%$ \\
\hline Gasoline & 2.77 & 3.03 & $+9 \%$ & 196.20 & 215.22 & $+10 \%$ \\
\hline Hybrid-diesel & 2.19 & 2.58 & $+18 \%$ & 153.00 & 182.65 & $+19 \%$ \\
\hline Hybrid-gasoline & 2.41 & 2.63 & $+9 \%$ & 168.30 & 183.88 & $+9 \%$ \\
\hline
\end{tabular}

When using the occupancy rates of 1.3 and 2.0 persons per vehicle, respectively, for short and long journeys, we obtain new factors per person kilometre as shown together with the old ones in Table 5.

Table 5. Old and new factors for energy consumption and $\mathrm{CO}_{2 \mathrm{eq}}$ emissions per passenger kilometre for passenger cars.

\begin{tabular}{|c|c|c|c|c|c|c|c|c|c|c|c|c|}
\hline & \multicolumn{6}{|c|}{ Short Journeys } & \multicolumn{6}{|c|}{ Long Journeys } \\
\hline & \multicolumn{3}{|c|}{ Energy (MJ/pkm) } & \multicolumn{3}{|c|}{$\mathrm{CO}_{2 \mathrm{eq}}(\mathrm{g} / \mathrm{pkm})$} & \multicolumn{3}{|c|}{ Energy (MJ/pkm) } & \multicolumn{3}{|c|}{$\mathrm{CO}_{2 \mathrm{eq}}(\mathrm{g} / \mathrm{pkm})$} \\
\hline & Old & New & Diff. & Old & New & Diff. & Old & New & Diff. & Old & New & Diff. \\
\hline TtW Diesel & 1.28 & 1.59 & $+25 \%$ & 94.69 & 118.40 & $+25 \%$ & 0.83 & 1.04 & $+25 \%$ & 61.55 & 76.96 & $+25 \%$ \\
\hline TtW Gasoline & 1.45 & 1.65 & $+14 \%$ & 106.77 & 121.40 & $+14 \%$ & 0.94 & 1.07 & $+14 \%$ & 69.40 & 78.91 & $+14 \%$ \\
\hline TtW Hybrid-diesel & 1.02 & 1.28 & $+25 \%$ & 76.23 & 95.23 & $+25 \%$ & 0.67 & 0.83 & $+25 \%$ & 49.55 & 61.90 & $+25 \%$ \\
\hline TtW Hybrid-gasoline & 1.18 & 1.35 & $+14 \%$ & 87.69 & 99.68 & $+14 \%$ & 0.77 & 0.88 & $+14 \%$ & 57.00 & 64.79 & $+14 \%$ \\
\hline WtT Diesel & 0.21 & 0.27 & $+31 \%$ & 18.08 & 22.98 & $+27 \%$ & 0.14 & 0.18 & $+31 \%$ & 11.75 & 14.93 & $+27 \%$ \\
\hline WtT Hybrid-diesel & 0.16 & 0.21 & $+31 \%$ & 14.54 & 18.35 & $+26 \%$ & 0.11 & 0.14 & $+31 \%$ & 9.45 & 11.93 & $+26 \%$ \\
\hline \multicolumn{13}{|c|}{ Sum TtW + WtT: } \\
\hline Diesel & 1.97 & 2.35 & $+19 \%$ & 138.85 & 167.46 & $+21 \%$ & 1.28 & 1.53 & $+19 \%$ & 90.25 & 108.85 & $+21 \%$ \\
\hline Gasoline & 2.13 & 2.33 & $+10 \%$ & 150.92 & 165.55 & $+10 \%$ & 1.39 & 1.52 & $+10 \%$ & 98.10 & 107.61 & $+10 \%$ \\
\hline Hybrid-diesel & 1.68 & 1.99 & $+18 \%$ & 117.69 & 140.50 & $+19 \%$ & 1.10 & 1.29 & $+18 \%$ & 76.50 & 91.32 & $+19 \%$ \\
\hline Hybrid-gasoline & 1.85 & 2.02 & $+9 \%$ & 129.46 & 141.45 & $+9 \%$ & 1.21 & 1.31 & $+9 \%$ & 84.15 & 91.94 & $+9 \%$ \\
\hline
\end{tabular}

As a result of the underreporting of emission data, the NEDC test cycle is being replaced with the WLTP (Worldwide harmonized Light-vehicles Test Procedure). This test is stricter and better approximates normal driving. The duration of the test is increased from 20 to $30 \mathrm{~min}$, the average speed from 34 to $46.5 \mathrm{~km} / \mathrm{h}$ and the temperature lowered from today's $20-30{ }^{\circ} \mathrm{C}$ to $14{ }^{\circ} \mathrm{C}$. In addition, the possibility of cheating with air and roll resistance is eliminated.

\section{Discussion}

We have provided a quantified estimate of the climate emissions consequences of reducing $\mathrm{NO}_{\mathrm{x}}$ exhaust emissions from internal combustion engine-based passenger transport running on gasoline and diesel, using available technologies. The actions and measures that automobile manufacturers are implementing for reducing $\mathrm{NO}_{\mathrm{x}}$ emissions have been shown to have the effect of increasing climate gas emissions, inadvertently negatively impacting climate policy goals. Through a review of the principles of the three most common technologies for reducing $\mathrm{NO}_{\mathrm{x}}$ emissions, together with their contribution to increased energy use and climate change gas emissions, estimates for adjustments to emission and energy use factors are elucidated. In addition, the recent studies in the aftermath of the diesel scandal, presenting higher, real-life fuel consumption than the car manufacturers claim, are taken into consideration.

The result of the assessment of the three technologies EGR, SCR and LNT, plus the under-reporting of fuel consumption from the car manufacturers, show that the new factors for energy consumption and emissions of $\mathrm{CO}_{2}$ equivalents justify additions in the range of $18-21 \%$ for diesel and hybrid diesel engine, while for gasoline and hybrid gasoline engines the addition is in the range of $9-10 \%$. The additions to the factors for both long and short trips are within these ranges. These are adjustments 
that have been taken into consideration in the updated version of the database for emissions and energy use, http:/ / transport.vestforsk.no/, developed by Vestlandsforsking.

The above analysis highlights a key environmental dilemma of current automobile fleets. It also illustrates, symptomatically, the path-dependent ways of thinking that have been prevalent within the sector, which have led to a quite profound form of what sociotechnical theorists describe as 'regime resistance'. As the shift to EVs begins but also stutters, with annual growth rates in EV adoption declining [57], it is also clear that public policy support will remain indispensable (ibid.) if the fossil-fuelled internal combustion engine is to return to its niche of the early 1900s.

As an area for further related policy research, attention might be given to the way in which automotive manufacturers have been operating within a regulatory regime that has favoured diesel for its better performance from a climate emissions reduction perspective, relative to gasoline. Europe has become a "diesel-island" —at least in comparison with the US—as recently pointed to in [58]. Given the stringent regulations for both reducing $\mathrm{CO}_{2}$ emissions and a strict $\mathrm{NO}_{x}$ emission regime, manufacturers have apparently been unable to comply without the use of cheating devices or under-reporting engine emissions. From this we infer that policy and regulation for local $\left(\mathrm{NO}_{\mathrm{x}}\right)$ and global $(\mathrm{GHG})$ emissions need to be tightly coupled. In the absence of other technological options for existing engines, such coupling points, there is again a need to move beyond fossil-fuelled engines.

\section{Policy Implications}

The 'diesel scandal' can be viewed in different ways from a policy point of view: firstly, it can be viewed as an example of a policy creating unintended consequences; i.e., policies aimed at solving one problem (reducing $\mathrm{NO}_{\mathrm{x}}$ emissions) creating another problem (increasing $\mathrm{CO}_{2}$ emissions). The solution to this situation is to supplement the initial policy measure with one that addresses the unintended consequence. This is a situation that has frequently occurred in the history of environmental policymaking [59]. At least, this would have been the situation without the cheating and general under-reporting taking place: the $\mathrm{NO}_{x}$ problem only appeared to be addressed. Therefore, we must view the diesel scandal differently.

A second option could be to view the diesel scandal as an example of a failed attempt at policy integration, such integration being increasingly common in environmental policy making [60]. Reducing $\mathrm{NO}_{\mathrm{x}}$ emissions belongs to the part of environmental policy working on reducing local—often health-related-environmental problems, whereas reducing $\mathrm{CO}_{2}$ emissions is the core part of climate policy. A diesel car usually has lower direct $\mathrm{CO}_{2}$ emissions per $\mathrm{km}$ than the petrol version of the same car; thus countries (for example Norway) have introduced policy measures that favour diesel before petrol fueled cars as part of their climate policy as an attempted means of policy integration. Thus, we have two conflicting policy streams: one acting to reduce $\mathrm{NO}_{\mathrm{x}}$-which leads to increased direct $\mathrm{CO}_{2}$ emissions per $\mathrm{km}$ for diesel cars (at least if done without the diesel cheat); and one acting to reduce $\mathrm{CO}_{2}$ by means of favouring diesel-fueled private cars-which leads to increased demands for diesel-fueled cars.

In this case, the policy failure relates to apparently insurmountable challenges arising from the relationships between engine temperature and combustion efficiency, leading to cheating and under-reporting of $\mathrm{NO}_{x}$ emissions and fuel consumption. Thus, while diesel engines appeared to offer a technological mitigation of both a local and global problem, representing an expression of policy integration, in practice the diesel scandal ends up as an example of policy non-integration.

This raises the question of why and how such a deceit has continued for so long. We suggest that viewing the diesel scandal as an example of regime resistance [4] would help to provide such an understanding. Telling the full narrative of this regime resistance and the wider story of auto-manufacturers' resistance to moving away from fossil-fueled combustion has not been our focus here. In fact, the drama of this story merits far more than a simple paper. In many ways it symbolises the story of our times, as we transition from previous ways of thinking. In doing so, we need to keep the lessons of the case, of policy studies and sociotechnical theory in mind: staying aware of 
the need to keep local pollution and climate policies integrated, considering the possible negative interactions between the two policy streams, seeking better policy mixes and being more conscious of the understandable motivations to resist change through whatever means.

Supplementary Materials: The following are available online at http:/ /www.mdpi.com/2071-1050/10/7/2313/ s1.

Author Contributions: C.A. conceptualized and acquired funding for the research. O.A. conceived the methodology, and performed the calculations and analysis of the data, and also wrote the major part of the paper. P.U. contributed with policy and regulatory context as well as assurance of structural coherence of the manuscript, and also provided stylistic and English-language improvements to the text.

Conflicts of Interest: The authors declare no conflict of interest. The founding sponsors had no role in the design of the study; in the collection, analyses, or interpretation of data; in the writing of the manuscript, and in the decision to publish the results.

\section{Abbreviations}

The following abbreviations are used in this manuscript:

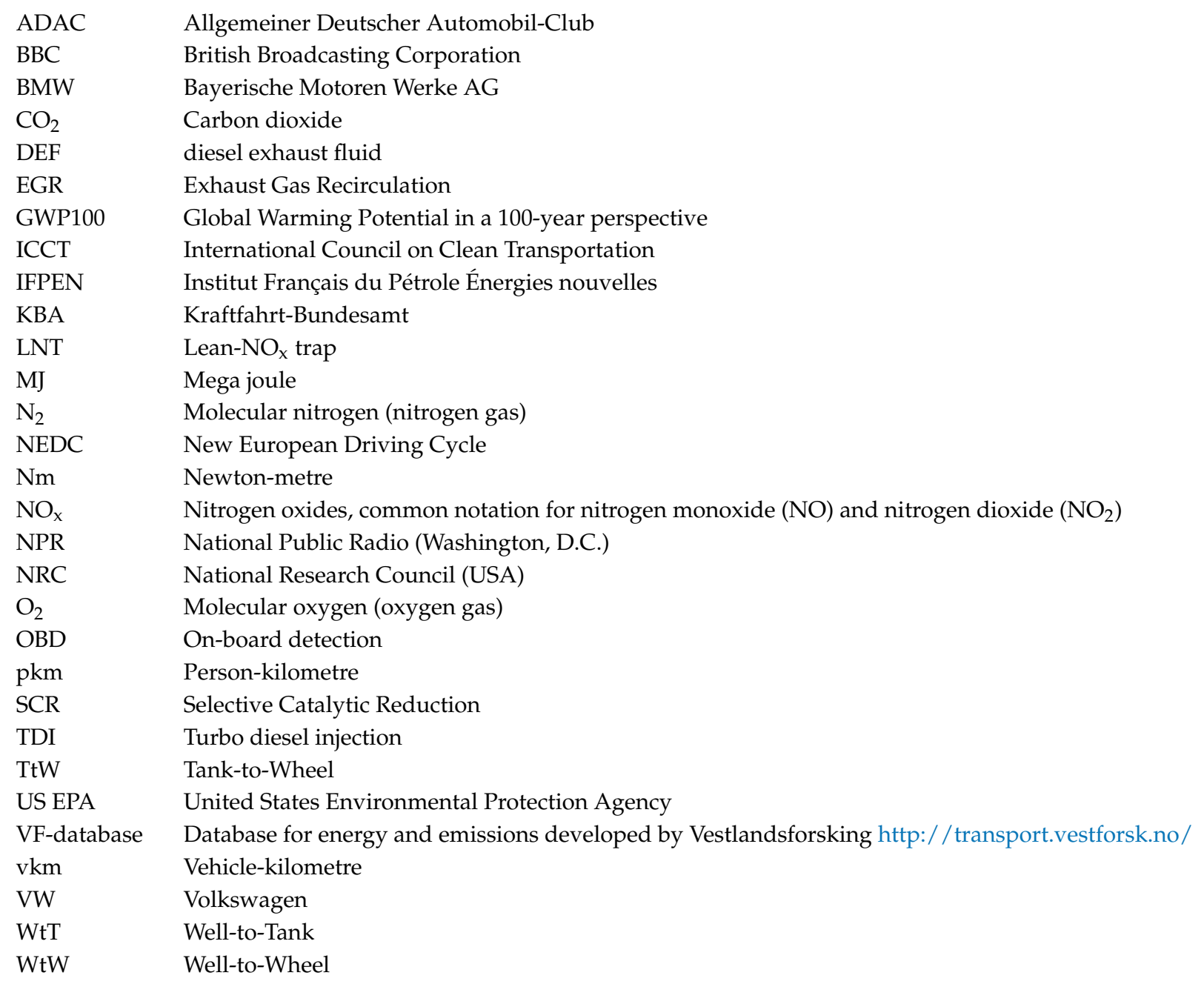

\section{References}

1. Hoen, A.; Geurs, K.; de Wilde, H.; Hanschke, C.; Uyterlind, M. CO Emission Reduction in Transport. Confronting Medium-Term and Long-Term Options for Achieving Climate Targets in The Netherlands; Netherlands Environmental Assessment Agency: The Hague, The Netherlands, 2009; Available online: http: / /www. rivm.nl/bibliotheek/rapporten/500076009.pdf (accessed on 16 April 2018). 
2. Doyle, A.; Muneer, T. 10—A Case Study for Northern Europe BT-Electric Vehicles: Prospects and Challenges; Elsevier: New York, NY, USA, 2017; pp. 341-385.

3. NPR. It Was Installed for This Purpose. VW's U.S. CEO Tells Congress about Defeat Device. The Two-Way. Breaking News from NPR, 2015. Available online: http:/ /www.npr.org/sections/thetwo-way/2015/10/08/ 446861855/volkswagen-u-s-ceo-faces-questions-on-capitol-hill (accessed on 7 June 2017).

4. Geels, F.W. Regime Resistance against Low-Carbon Transitions: Introducing Politics and Power into the Multi-Level Perspective. Theory Cult. Soc. 2014, 31, 21-40. [CrossRef]

5. Kemp, R.; Schot, J.; Hoogma, R. Regime Shifts to Sustainability through Processes of Niche Formation: The Approach of Strategic Niche Management. Technol. Anal. Strateg. Manag. 1998, 10, 175-198. [CrossRef]

6. Upham, P.; Kivimaa, P.; Virkamäki, V. Path dependency in transportation system policy: A comparison of Finland and the UK. J. Transp. Geogr. 2013, 32, 12-22. [CrossRef]

7. Fortune. How VW Paid \$25 Billion for 'Dieselgate'-And Got Off Easy. 2018. Available online: http: / / fortune.com/2018/02/06/volkswagen-vw-emissions-scandal-penalties/ (accessed on 16 May 2018).

8. Kriegler, E.; Luderer, G.; Bauer, N.; Baumstark, L.; Fujimori, S.; Popp, A.; Rogelj, J.; Strefler, J.; van Vuuren, D.P. Pathways limiting warming to $1.5^{\circ} \mathrm{C}$ : A tale of turning around in no time? Philos. Trans. R. Soc. A Math. Phys. Eng. Sci. 2018, 376, 20160457. [CrossRef] [PubMed]

9. Bows, A.; Anderson, K.; Upham, P. Aviation and Climate Change: Lessons from European Policy; Routledge: Abingdon, UK, 2008.

10. Meinshausen, $\mathrm{M}$. What does a $2{ }^{\circ} \mathrm{C}$ target mean for greenhouse gas concentrations? - A brief analysis based on multi-gas emission pathways and several climate sensitivity uncertainty estimates. In Avoiding Dangerous Climate Change; Schellenuber, H.J., Ed.; Cambridge University Press: Cambridge, UK, 2006; pp. 265-279.

11. European Commission (EC). A European Strategy for Low-Emission Mobility; European Commission: Brussels, Belgium, 2016; Available online: https:/ / ec.europa.eu/clima/policies/transport_en\#tab-0-0 (accessed on 16 May 2018).

12. Houghton, J.T.; Jenkins, G.J.; Ephraums, J.J. Climate Change: The IPCC Scientific Assessment; IPCC: Geneva, Switzerland, 1990.

13. European Environment Agency (EEA). Air Quality in Europe-2017 Report; EEA Report No 13/2017; European Environment Agency: Copenhagen, Denmark, 2017.

14. European Society of Cardiology. Diesel pollution linked to heart damage: $\mathrm{PM}_{2.5}$ associated with harmful changes to heart structure and function; higher education protective against the damage. ScienceDaily. 26 May 2017. Available online: www.sciencedaily.com/releases/2017/05/170526084541.htm (accessed on 16 May 2018).

15. European Union (EU). Directive 2008/50/EC of the European Parliament and of the Council of 21 May 2008 on Ambient Air Quality and Cleaner Air for Europe; European Union: Brussels, Belgium, 2008; Available online: http: / / eur-lex.europa.eu/legal-content/EN/TXT / ?qid=1486474738782\&uri=CELEX:02008L005020150918 (accessed on 24 May 2018).

16. United States Environmental Protection Agency (US EPA). Volkswagen Violations. 2016. Available online: https: / / www.epa.gov /vw / laws-and-regulations-related-volkswagen-violations (accessed on 16 May 2018).

17. Halse, A.; Flügel, S.; Killi, M. Korte og Lange Reiser (Tilleggsstudie)_Verdsetting av tid, Pålitelighet og Komfort; TØI: Oslo, Norway, 2010; Available online: https:/ / www.toi.no/getfile.php?mmfileid=16086 (accessed on 16 May 2018).

18. Simonsen, M. Transport, Energi og Miljø (Transport, Energy and Environment); Vestlandsforsking: Sogndal, Norway, 2010; Available online: http://sip1.vestforsk.no/pdf/Felles/Sluttrapport.pdf (accessed on 16 May 2018).

19. Transport \& Environment. Dieselgate: Who? What? How? Transport \& Environment: Brussels, Belgium, 2016; Available online: https://www.transportenvironment.org/sites/te/files/publications/2016_09_Dieselgate_ report_who_what_how_FINAL_0.pdf (accessed on 7 June 2017).

20. NPR. Volkswagen Used “Defeat Device” To Skirt Emissions Rules, EPA Says. The Two-Way. Breaking News from NPR, 2015. Available online: http:/ / www.npr.org/sections/thetwo-way/2015/09/18/441467960/ volkswagen-used-defeat-device-to-skirt-emissions-rules-epa-says (accessed on 7 June 2017).

21. Thompson, G.J.; Carder, D.K.; Besch, M.C.; Thiruvengadam, A.; Kappanna, H.K. In-Use Emissions Testing of Light-Duty Diesel Vehicles in the United States; CAFEE-Center for Alternative Fuels, Engines \& Emissions, 
West Virginia University: Morgantown, WV, USA, 2014; Available online: http: / www.theicct.org/sites / default/files / publications/WVU_LDDV_in-use_ICCT_Report_Final_may2014 (accessed on 7 June 2017).

22. International Council on Clean Transportation (ICCT). EPA's Notice of Violation of the Clean Air Act to Volkswagen. 2015. Available online: http:/ / www.theicct.org/sites/default/files/press-factsheet-combo_ EPA-CARB-VW_20150918.pdf (accessed on 6 June 2017).

23. Carrington, D. Four more carmakers join diesel emissions row. The Guardian. 9 October 2015. Available online: https:/ / www.theguardian.com/environment/2015/oct/09/mercedes-honda-mazda-mitsubishidiesel-emissions-row?CMP=twt_gu (accessed on 6 June 2017).

24. Carrington, D. Wide range of cars emit more pollution in realistic driving tests, data shows. The Guardian. 30 September 2015. Available online: https:/ / www.theguardian.com/environment/2015/sep/30/widerange-of-cars-emit-more-pollution-in-real-driving-conditions-tests-show (accessed on 6 June 2017).

25. IFPEN. Contrôle des Émissions de Polluants Atmosphériques et de $\mathrm{CO}_{2}$ Mené sur 86 Véhicules. IFP Énergies Nouvelles; Ministre de l'Environnement. de l'Énergie et de la Mer: France, 2016; Available online: https:/ / www.actu-environnement.com/media/pdf/news-27305-rapport-commission-enqueteemissions-vehicules.pdf (accessed on 6 June 2017).

26. Lie, Ø. Alle Dieselmerkene Forurenset mer enn Volkswagen, Fiat, Suzuki og Renault Blant Verstingene, Ifølge ny Studie; Teknisk Ukeblad: Oslo, Norway, 2016; Available online: http: / /www.tu.no/artikler / alledieselmerkene-forurenset-mer-enn-volkswagen/354608 (accessed on 7 June 2017).

27. Omnagen.com. Guide to Pollution Caused by Diesel Engines, Omnagen—Sustainable Energy from Chemical Processes. 2016. Available online: http:/ / omnagen.com/nox-emissions.html (accessed on 7 June 2017).

28. ICCT. FAQ: In-Use $\mathrm{NO}_{\mathrm{x}}$ Emissions from Diesel Passenger Cars. International Council on Clean Transportation, 2016. Available online: http://www.theicct.org/news/faq-use-nox-emissions-diesel-passenger-cars (accessed on 6 June 2017).

29. Hussain, J.; Palaniradja, K.; Alagumurthi, N.; Manimaran, R. Effect of Exhaust Gas Recirculation (EGR) on Performance and Emission characteristics of a Three Cylinder Direct Injection Compression Ignition Engine. Alex. Eng. J. 2012, 51, 241-247. Available online: http://www.sciencedirect.com/science/article/pii/ S1110016812000907 (accessed on 6 June 2017). [CrossRef]

30. Wagner, R.; Green, J.; Dam, T.; Edwards, K. Simultaneous Low Engine-Out NO $\mathrm{x}_{\mathrm{x}}$ and Particulate Matter with Highly Diluted Diesel Combustion; SAE Technical Paper; Oak Ridge National Laboratory: Oak Ridge, TN, USA, 2003.

31. NRC. Review of the 21st Century Truck Partnership; The National Academies Press: Washington, DC, USA, 2008.

32. Ramsdal, R. Færre Hestekrefter kan bli Løsningen for VWs Skandalebiler. 2015. Available online: http: / / www.tu.no/artikler/faerre-hestekrefter-kan-bli-losningen-for-vws-skandalebiler/275715 (accessed on 7 June 2017).

33. Nikolaisen, P.-I.; Valmotodd, O.R.; Valmot, R. VW-Skandalen: De er Utslippsjegerne Ingen Lurer. 2015. Available online: http:/ /www.tu.no/artikler/vw-skandalen-de-er-utslippsjegerne-ingen-lurer/275864 (accessed on 7 June 2017).

34. Smirnow, A. How Much Power Does the VW TDI Lose in "Cheater" Mode? (Video Report). 2015. Available online: http:/ / www.tflcar.com/2015/10/how-much-power-does-the-vw-tdi-lose-in-cheater-mode-videoreport/ (accessed on 7 June 2017).

35. VW. $\mathrm{NO}_{\mathrm{x}}$-Thematik: Kunden Werden Informiert. Umsetzung Beginnt. 2015. Available online: https: / www.volkswagen-media-services.com/detailpage/- / detail/NOx-Thematik-Kunden-werdeninformiert-Umsetzung-beginnt/view / 2995368/399f26f9f462026b24034ba716bcbdeb?p_p_auth=sk1G6prN (accessed on 7 June 2017).

36. VW. Volkswagen Beginnt in Europa mit der Umsetzung der Technischen Maßnahmen bei den EA189-Dieselmotoren. Volkswagen Aktuell, 2016. Available online: https://www.volkswagen-mediaservices.com/detailpage/-/detail/Volkswagen-beginnt-in-Europa-mit-der-Umsetzung-der-technischenManahmen-bei-den-EA189-Dieselmotoren/view/3148265/212dd9f7c8dfa7364535182c5610a73e?p_p_auth= V9zOin8u (accessed on 7 June 2017).

37. Tatarevic, B. How the Volkswagen Dirty Diesel “Flow Straightener" Really Works. 2015. Available online: http: / / www.thetruthaboutcars.com/2015/12/vw-flow-straightener-really-works / (accessed on 7 June 2017). 
38. Bell Performance. Getting Good Gas Mileage-The 3 Engine Components You Need to Check. 2012. Available online: https:/ / www.bellperformance.com/blog/bid/110805/getting-good-gas-mileage-the-3engine-components-you-need-to-check (accessed on 6 June 2017).

39. VW. Freigabe der Technischen Lösungen für Rund 1.1 Millionen Weitere Konzern-Fahrzeuge Durch das Kraftfahrt-Bundesamt Bestätigt. 2016. Available online: https://www.volkswagen-media-services. com/detailpage/-/detail/Freigabe-der-technischen-Lsungen-fr-rund-11-Millionen-weitere-KonzernFahrzeuge-durch-das-Kraftfahrt-Bundesamt-besttigt/view /3641326/6e1e015af7bda8f2a4b42b43d2dcc9b5? P_p_auth=uxg76k1Q (accessed on 7 June 2017).

40. Gulde, D. VW-Diesel-Software-Update: VW Amarok Leistung Gleich-Verbrauch Leicht Erhöht. Verbrauch: Steigt um Mehr als 0.5 Litre je $100 \mathrm{~km}$. Auto Motor und Sport, 2016. Available online: http:/ / www.auto-motor-und-sport.de/news/vw-diesel-update-amarok-leistung-gleich-gut-verbrauchleicht-erhoeht-10551733.html (accessed on 6 June 2017).

41. KBA. Bericht der Untersuchungskommission "Volkswagen". Untersuchungen und verwaltungsrechtliche Maßnahmen zu Volkswagen. Ergebnisse der Felduntersuchung des Kraftfahrt-Bundesamtes zu unzulässigen Abschalteinrichtungen bei Dieselfahrzeugen und Schlussfolgerungen. Bundesministeriums für Verkehr und digitale Infrastruktur (BMVI) Invalidenstraße 44. 10115 Berlin. , 2016. Available online: http:/ / www.autoevolution.com/pdf/ news_attachements /630000-diesel-cars-of-german-origin-to-be-recalled-in-europe-more-to-follow-106820.pdf (accessed on 6 June 2017).

42. Panait, M. 630,000 Diesel Cars of German Origin to Be Recalled in Europe. More to Follow. AutoEvolution, 2016. Available online: http:/ /www.autoevolution.com/news /630000-diesel-cars-of-german-origin-to-berecalled-in-europe-more-to-follow-106820.html (accessed on 7 June 2017).

43. Olsen, S.J. Ny Utslippsavsløring: Skrur av Eksosrensingen Allerede ved 17 Grader; Teknisk Ukeblad: Oslo, Norway, 2016; Available online: http:/ / www.tu.no/artikler/nye-dieselgate-funn-bilprodusentene-skrurav-eksosrensing-allerede-ved-17-grader/347699 (accessed on 7 June 2017).

44. Poliscanova, J. \#Dieselgate Continues: New Cheating Techniques. How National Investigations into Emissions Scandal Are Pointing to Existence of New Defeat Devices. 2016. Available online: https:// www.transportenvironment.org/sites/te/files/publications/2016_05_Dieselgate_continues_briefing.pdf (accessed on 7 June 2017).

45. Valle, M. Slik Skal Forbrenningsmotoren bli Renere. 2016. Available online: http://www.tu.no/artikler/slikskal-forbrenningsmotoren-bli-renere/276758 (accessed on 7 June 2017).

46. Mårtensson, L. Emissions from Volvo's Trucks, Volvo Trucks Global. 2014. Available online: http:/ / www.volvotrucks. com/SiteCollectionDocuments/VTC/Corporate/Aboutus/Environment-2014/Emis_eng_10110_14001.pdf (accessed on 7 June 2017).

47. Baquero, G.; Esteban, B.; Puig, R.; Jordi-Roger, R.; Antoni1, R. Environmental life cycle assessment of rapeseed straight vegetable oil as selfsupply agricultural biofuel. Renew. Energy 2013, 50, 142-149.

48. Skowrońska, M.; Filipek, T. Life cycle assessment of fertilizers: A review. Int. Agrophys. 2014, 28, 101-110. [CrossRef]

49. VW. Aufklärung Wird Vorangetrieben: Volkswagen Stellt bei Internen Untersuchungen Unregelmäßigkeiten bei $\mathrm{CO}_{2}$-Werten Fest. 2015. Available online: https:/ / www.volkswagen-media-services.com/detailpage/-/ detail/Aufklrung-wird-vorangetrieben-Volkswagen-stellt-bei-internen-Untersuchungen-Unregelmigkeitenbei-CO2-Werten-fest/view / 2857360/18108d8d101b6284fe7b29bcf415eda5?p_p_auth=W9vmBa7g (accessed on 7 June 2017).

50. VW. Nächster Schritt in der Aufklärung der $\mathrm{CO}_{2}$-Thematik. 2015. Available online: https://www. volkswagen.at/news-magazin/news/18-naechster-schritt-in-der-aufklaerung-der-co2-thematik (accessed on 7 June 2017).

51. BBC Volkswagen Says 800.000 Cars May Have False $\mathrm{CO}_{2}$ Levels. 2015. Available online: http:/ / www.bbc. com/news/business-34712435 (accessed on 6 June 2017).

52. Cremer, A. VW Says $\mathrm{CO}_{2}$ Emissions Scandal Not as Bad as Feared. 2015. Available online: http:/ / www. reuters.com/article/us-volkswagen-emissions-carbon-idUSKBNOTS12I20151209 (accessed on 6 June 2017).

53. Tietge, U.; Zacharof, N.; Mock, P.; Franco, V.; German, J.; Bandivadekar, A.; Ligterink, N.; Lambrecht, U. From Laboratory to Road. A 2015 Update of Official and "Real-World" Fuel Consumption and $\mathrm{CO}_{2}$ Values for Passenger Cars in Europe. International Council on Clean Transportation, 2015. Available 
online: http:/ / www.theicct.org/sites / default/files / publications /ICCT_LaboratoryToRoad_2015_Report_ English.pdf (accessed on 7 June 2017).

54. Emissions Analytics. EQUA Fuel Economy Index. 2016. Available online: http:/ / equaindex.com/ (accessed on 6 June 2017).

55. Simonsen, M. Energibruk og Utslipp fra Persontransport med Personbil. En livsløpsanalyse. Vestlandsforsking: Sogndal, 2010. Available online: http:/ / sip1.vestforsk.no/pdf/Personbil/PersontransportBil.pdf (accessed on 16 May 2018).

56. Holmengen, N.; Fedoryshyn, N. Utslipp fra Veitrafikken i Norge Dokumentasjon av Beregningsmetoder, Data og Resultater; Notater 2015/22; Statistics Norway: Oslo, Norway, 2015. Available online: https: / www.ssb.no/ natur-og-miljo/artikler-og-publikasjoner/_attachment/225115?_ts=14ce05a5658 (accessed on 6 June 2017).

57. International Energy Agency (IEA). Global EV Outlook 2017; International Energy Agency: Paris, France, 2017.

58. Hooftman, N.; Messagie, M.; Van Mierlo, J.; Coosemans, T. A review of the European passenger car regulations-Real driving eissions vs local air quality. Renew. Sustain. Energy Rev. 2018, 86, 1-21. [CrossRef]

59. Andersen, O. Unintended Consequences of Renewable Energy. Problems to Be Solved; Springer: London, UK, 2013.

60. Aall, C.; Todds, R.; Sælensminde, I.; Brendehaug, E. Introducing the concept of Environmental Policy Integration into the discourse on Sustainable Tourism: A way to improve policymaking? J. Sustain. Tour. 2015, 23, 977-989. [CrossRef]

(C) 2018 by the authors. Licensee MDPI, Basel, Switzerland. This article is an open access article distributed under the terms and conditions of the Creative Commons Attribution (CC BY) license (http:/ / creativecommons.org/licenses/by/4.0/). 